\title{
Demand for money in Macedonia
}

\begin{abstract}
The existence of a stable long-run demand for money is important for conducting monetary policy for two main reasons: first, a stable demand for money represents a prerequisite for supplying an adequate quantity of money in accordance with the needs of businesses and households; second, the stability of the demand for money is a necessary condition for implementing monetary policy strategies in which monetary aggregates have a prominent role. Our main goals are to analyse the longrun relationship between money and several other variables in Macedonia; to examine the short-run dynamics of the demand for money; and to assess the properties of stability of the money demand function. The properties of the long-run demand for money are explored within the context of a co-integration approach, while the short-run dynamics are analysed employing an error-correction model. Our research reveals that the income elasticity of the demand for money is less than unitary, the short-run adjustment toward long-run equilibrium is rather slow and the estimated demand for money seems to be quite stable.
\end{abstract}

Keywords: co-integration, error-correction model, money demand, monetary policy

\section{Introduction}

Undoubtedly, monetary aggregates seem to be important for monetary policy authorities, especially in the context of economic programmes in which performance criteria are determined by the use of limits on the monetary base or on other monetary aggregates. In these regards, models of the demand for money represent a natural benchmark against which to assess monetary developments. As a matter of fact, they also provide a framework for distinguishing changes in money, as explained by developments in various macroeconomic variables. Hence, the role of monetary aggregates needs to be determined from a policy-making perspective. Here, estimating the demand for money becomes a vital focus, since the empirical relationship represented by the money demand equation enables us to examine the interaction between monetary aggregates and other economic indicators.

The purpose of this article is to develop a money demand function for narrow money in Macedonia and to examine the constancy of this relationship during the post-stabilisation period. From a methodological point of view, we employ the Vector Error Correction Model (VECM) where first we test for and estimate the cointegrating relationship between money and several variables; and then we model the short-run adjustment toward equilibrium, as represented by the error correction term. The sample covers the period from 1997 to 2008, and we work with quarterly data. 
The rest of the article is organised as follows: it first discusses the basic model of the money demand function and gives an overview of the variables entering the money demand equation. The next section provides a brief overview of empirical research into the demand for money, followed by a focus on the issues related to the data and methodology used in the analysis. The next section discusses the estimation procedure, including the unit root tests, the co-integration analysis and the error-correction model. Finally, we summarise the estimation results and their implications, assessing some of the probable conclusions that can be drawn.

\section{Theoretical background - money demand function}

The demand for money represents the desire of households and businesses to hold assets in a form that can be easily exchanged for goods and services. In these regards, spending ability, or liquidity, is the key aspect of money that distinguishes it from other types of asset. For this reason, the demand for money is sometimes called demand for liquidity. Further on, demand for money is often broken into two distinct categories: transactions demand; and speculative demand.

The primary reason why economic agents hold money is because they expect to use it to buy goods and services sometime in the future. In other words, the meaning of holding money is that people expect to make transactions for goods or services. How much money a person holds should probably depend upon the value of the transactions that are anticipated. This is what the theory refers to as the transactions demand for money. However, in this section we are not interested so much in an individual's demand for money but rather in what determines the aggregate demand for money. Extrapolating from the individual to the group, we could conclude that the total value of all transactions in the economy in a given period would influence the aggregate transactions demand for money. Simply stated, there will be a greater demand for money as economic agents undertake more transactions, i.e. they purchase more goods and services.

The second type of money demand arises after a consideration of the opportunity cost of holding money. In these regards, alternative opportunities include holding wealth in the form of savings deposits, mutual funds, stock, real estate or even physical assets. For many of these alternative assets, interest payments - or at least a positive rate of return - are desirable while, at the same time, money usually does not bring any return. Holding money is costly, i.e. there is an opportunity cost, so the demand for money should be affected by changes in its opportunity cost. The interest rate on each economic agent's next best opportunity may differ between the holders of money, so we can use the average interest rate in the economy as a proxy for the opportunity cost. In this sense, it is likely that, as average interest rates rise, the opportunity cost of holding money will also rise, for all money holders, thus reducing the quantity of money demanded.

Given the short description given above, the money demand function tends to display the influence that some economic aggregate variables will have upon the aggregate quantity of money that economic agents desire to hold. This discussion indicates that the nominal demand for money will depend positively on the level of economic activity and the price level due to the demand for transactions. However, the demand for money 
will depend negatively on average interest rates due to speculative concerns. We can depict these relationships simply using the following functional representation:

$$
M^{D}=f(\stackrel{+}{P}, \stackrel{+}{Y}, \stackrel{-}{i})
$$

where, $M^{D}$ is the aggregate, economy-wide demand for money; $P$ is the current price level; $Y$ represents economic activity; and $i$ is the average interest rate.

The money demand function is often transformed into a real money demand function. First, we may re-write the right-hand side of equation (1) to obtain:

$$
M^{D}=P \times L(Y, i)
$$

In this version, the price level, $P$, is brought outside the function $f($.$) and multiplied$ by a new function, labelled $L($.), and called the liquidity function.

Finally, by moving the price level variable to the left hand side, we can write out the general form of the real money demand function as:

$$
\frac{M^{D}}{P}=L(\stackrel{+}{Y}, i)
$$

Equation (3) states that real money demand, $M^{D} / P$, is positively related to changes in real economic activity $(Y)$ and the average interest rate $(i)$. This representation of the demand for money implies that money is neutral in the long-run, i.e. that the money demand function is homogenous with respect to the price level.

\section{Empirical research into the demand for money}

The theoretical model of the demand for money, presented in equations (1) and (3), appears to be quite simple but, in empirical research, one faces issues related to the selection of the appropriate variables that are to be included in the analysis. In general, real money balances are related to some scale measure, such as income or wealth, and some opportunity cost measures, such as interest rates and inflation. However, there are different approaches to the exact form of the money demand function and the selection of the variables entering the equation. Thus, the choice of economic indicators varies in different country experiences due to the distinction in different financial systems.

Choosing an adequate monetary aggregate for the estimation of a meaningful demand for money function is challenging. Either a broad or a narrow definition of money can be used as the monetary variable, depending on the emphasis that monetary authorities put on alternative monetary aggregates. Generally, it may be thought that a narrow definition of money (like monetary base or M1) appears to be more flexible and reactive to market operations and, therefore, to interest rate policies. Narrow money can have a close relationship with prices, since it can easily be influenced by economic variables; however, it cannot always be adequate to capture all the information related to the financial system. Narrowly-defined aggregates are easy to control, but their relationship with income appears subject to considerable variability. One reason for this 
insufficiency is due to the banking habits of money holders, as they wish to hold their savings not only in demand deposits but also in time deposits, or other different financial instruments. Therefore, a broader definition of money, such as M2, can comprise a wider range of financial instruments yet may be less sensitive to the changes in the economy.

As mentioned, the first determinant of the money demand function is a scale variable measuring the level of economic activity. The demand for money is related to the volume of transactions, since the amount of transactions is proportionate to the level of income. Either a wealth variable or an income variable can be used as a scale variable. Generally, when wealth data is not available, an income variable like Gross National Product (GNP) or Gross Domestic Product (GDP), or even real wages, can be taken into consideration.

One of the most important aspects of modelling the demand for money is the selection of appropriate opportunity cost variables. In this sense, there are two major ingredients: own rate of return; and return on alternative assets. Demand for money is inversely related to market interest rates and the yields on different financial assets. However, the interest rate received on time deposits is thought to be the nominal return from holding money if the broad definition of money is considered, and hence has a positive sign in the demand for money equation. On the other side, the most serious candidate for measuring the opportunity cost of holding money is the interest rate on government securities, and its expected sign in the money demand function is therefore negative.

During the last two or three decades, a huge amount of empirical literature has accumulated in dealing with demand for money. Various studies differ with respect to the monetary aggregates analysed (narrow or broad money), the general approach (country-specific or panel data), the countries covered (industrialised or emerging economies) and the methodology (VECM, ARDL etc.), but they usually follow some standard procedure. A non-exhaustive list of studies into money demand comprises: Andersen (2004), Calza, Gerdesmeier and Levy (2001), Ericsson, Hendry and Prestwich (1998), Golinelli and Pastorello (2002) and Jonsson (2001) for industrialised countries; Bahmani-Oskooee and Ng (2002), Halicioglu and Ugur (2005), Mutluer and Barlas (2002), Nachega (2001), Piñón-Farah (1998) and Sriram (1999) for emerging economies; and Dreger, Reimers and Roffia (2006), Kalra (1999) and Siliverstovs (2007) for central and east European countries. To our best knowledge, no empirical analysis on the demand for money in Macedonia has been conducted so far.

In addition, Sriram (2001) provides an exhaustive review of the empirical literature on demand, especially that employing the ECM approach. He finds that the estimated income elasticity for narrow money ranges from 0.4 to 2 , although both the mean and the median estimates are closer to 1 than to 0.5 . Knell and Stix (2004) provide an even broader survey of almost 1000 money demand estimations extracted from three survey papers, including that of Sriram (2001). They find that income elasticity is lower for the demand for narrow money; it is higher in less developed countries, and the estimates range within a wider interval (from 0.4 to 1.6) although, once again, the mean and the median are often around one. 


\section{Data and methodology}

The empirical analysis of the demand for money in Macedonia is based on data sources obtained from the Research Division within the National Bank of Macedonia. The sample covers the period from the first quarter of 1994 up to the last quarter of 2008. We use the quarterly values of the following variables: narrow money, as represented by the monetary aggregate M1 (comprising cash plus sight deposits); Gross Domestic Product (GDP); and the interest rate on three-month time deposits, denominated in the domestic currency (DENDEP). In addition, nominal narrow money and GDP are deflated by the Consumer Price Index (CPI) and are expressed in natural logarithms.

We chose to model the demand for narrow money for several reasons. First, the definition of M1 in Macedonia is consistent with the definitions generally applied elsewhere, thus allowing comparison of the results. Second, M1 is closely associated with transactions, because it comprises the most liquid financial instruments, i.e. those that serve as a medium of exchange. Third, working with M1 allows for an unambiguous selection of the opportunity cost of holding money, because it eliminates the need for differentiating between own and external rates of return. Fourth, from the central bank's point of view, it is much easier for the monetary authorities to control narrow money than broader aggregates. Finally, one may argue that narrow money is more closely related to prices and other economic variables, especially in countries where the financial system is not so developed and the financial instruments are not sophisticated. Therefore, we think that a model based on narrow money will work better than one based on broader money (this was confirmed by our preliminary estimates of the money demand for M2).

In the empirical research into the demand for money, the general function (3) is usually represented in a log-linear form:

$(m-p)=\beta_{0}+\beta_{1} y+\beta_{2} r$

In this specification, the dependent variable is the real demand for money $(m-p)$, where money is represented by the monetary aggregate M1. It can be seen that we model money demand as the demand for real money, which implies that the model incorporates an assumption of price homogeneity. In turn, this assumption implies that money is neutral in the long run, i.e. that the demand to hold nominal money balances rises proportionally with an increase in prices.

Further, our modelling of the demand for narrow money means that the empirical model employed herein is consistent with the transactions demand for money, so real GDP is used as a measure of the volume of transactions. Concerning the last variable in equation (2), at least from a theoretical point of view, the yield on long-term bonds seems to be an adequate proxy for the opportunity cost. However, there are no relevant long-term interest rates that would play this role in Macedonia. So far, only a few twoyear government bonds have been issued, for which there is no active secondary market. In these circumstances, short-term interest rates are taken as representatives of the opportunity cost of money, because these financial instruments appear to be closer substitutes for money. Among the various short-term interest rates, the usual approach 
found in the empirical literature is to work with the yield on treasury bills. In Macedonia, treasury bills have been introduced only recently and, at the same time, they lack liquidity. Consequently, the use of interest rates on central bank bills (CB-bills) seems to be more promising.

However, we think that the interest rate on three-month time deposits provides a better measure of the opportunity cost compared to CB-bills for two reasons. First, the market for central bank bills is dominated by commercial banks, i.e. bank deposits are still the predominant form of financial assets in which the population and companies invest their excess money holdings. Second, there's no active secondary market for CBbills so, due to their low liquidity, they can hardly be regarded as close substitutes for money. In addition, the preliminary investigation of the properties of the time series has shown that CB-bills might not be integrated of the same order as the other variables included in the model, which might be a source of problems for the estimation.

Given the log-linear form of the empirical model, the coefficients before the independent variables measure the elasticity of the demand for money. However, the interest rate enters the model in levels rather than in logarithms, thus implying that the coefficient before this variable represents semi-elasticity. As for the signs and magnitudes of the coefficients, the main theoretical predictions are as follows: the quantity theory of money implies that $\beta_{1}=1$, while the Baumol-Tobin model asserts that $\beta_{1}=0.5$; and the coefficient before the opportunity cost of money should bear a negative sign. For these and other important issues in the empirical modelling of money demand, see Ericsson (1998).

\section{Estimation of the empirical model}

In the last two decades, the Vector Error Correction Model (VECM) has emerged as the usual methodology for analysing the demand for money, because it enables researchers to study both the long-run and the short-run dynamics of the economic variables. Within this framework, first the long-run relationship between the variables in equation (2) is studied by means of the cointegration technique; and then, in the second step, the ECM provides the tools for investigating the short-run dynamics.

Given that cointegration can be applied only to non-stationary variables, and which are integrated of the same order, we first examined the time series property of the variables considered for the empirical model. In this regard, it is well-known that macroeconomic time series often contain unit roots and that working with non-stationary data may lead to spurious regressions and to incorrect conclusions from the econometric exercise. Any linear combination of non-stationary series is also non-stationary, but Engle and Granger (1987) have shown that there may exist such a linear combination which is stationary. A necessary condition for this is that the variables should be integrated of the same order.

\section{Unit root tests}

The variables included in the empirical model were checked for stationarity, using the Augmented Dickey-Fuller (ADF) test. Given the small sample, the Schwarz Information Criterion was employed for determining the number of lags in the ADF test, in 
order to save degrees of freedom. Based on this information criterion, the ADF-test for $\mathrm{M} 1 / \mathrm{P}$ was performed with two lags in the test-equation; the test-equation for GDP included four lags; while the test for DENDEP did not include any lags, indicating that the basic DF-test was employed.

The results of the unit root tests performed on the levels of the variables are reported in Table 1. It can be seen that the test of the null hypothesis for the presence of a unit root reveals that GDP is clearly non-stationary, while two of the three test-variants show that money and the interest rate are non-stationary, too.

Table 1 - ADF unit root test

\begin{tabular}{|l|c|c|c|}
\hline \multirow{2}{*}{ Variable } & \multicolumn{3}{|c|}{ Variant of the test } \\
\cline { 2 - 4 } & Constant & $\begin{array}{c}\text { Constant and } \\
\text { trend }\end{array}$ & None \\
\hline $\log (M 1 / P)$ & -0.5212 & $-3.2586^{*}$ & 3.7079 \\
& $(0.8773)$ & $(0.0861)$ & $(0.9999)$ \\
\hline $\log (G D P)$ & 0.1832 & -1.7157 & 1.6652 \\
& $(0.9684)$ & $(0.7270)$ & $(0.9749)$ \\
\hline$D E N D E P$ & -1.9789 & -0.4943 & $-2.9542 * * *$ \\
& $(0.2949)$ & $(0.9804)$ & $(0.0040)$ \\
\hline
\end{tabular}

Note: *,** and $* * *$ denote rejection of the null at $10 \%, 5 \%$ and $1 \%$, respectively.

Given the slight uncertainty of the results, and taking into account the low power of the ADF-test in small samples, we decided to check for the stationarity properties of the variables by means of the Philips-Perron (PP) test. Table 2 shows that the PPtest does not dramatically change the previous results: here, M1 appeared to be clearly non-stationary, while there is some evidence that GDP and DENDEP might be stationary, depending on the variant of the test-equation employed. Overall, most of the tests suggest that all the variables, taken at different levels, are non-stationary.

Table 2 - PP unit root test

\begin{tabular}{|l|c|c|c|}
\hline \multirow{2}{*}{ Variable } & \multicolumn{3}{|c|}{ Variant of the test } \\
\cline { 2 - 4 } & Constant & $\begin{array}{c}\text { Constant and } \\
\text { trend }\end{array}$ & None \\
\hline $\log (M 1 / P)$ & -0.7309 & -2.5175 & 4.7137 \\
& $(0.8288)$ & $(0.3187)$ & $(1.0000)$ \\
\hline $\log (G D P)$ & -1.8672 & $-4.8076^{* * * *}$ & 3.1138 \\
& $(0.3445)$ & $(0.0017)$ & $(0.9993)$ \\
\hline$D E N D E P$ & -1.9605 & -0.5503 & $-2.9717^{* * *}$ \\
& $(0.3028)$ & $(0.9774)$ & $(0.0038)$ \\
\hline
\end{tabular}


Therefore, the unit root tests performed on the levels of the variables lead to the conclusion that money, GDP and interest rates are non-stationary. In order to see if they are integrated of the same order, we checked for the stationarity properties of the same variables taken as first differences. Here, once again, we employed the ADF and PP tests, which clearly showed that the null of a unit root can be rejected at the $1 \%$ significance level. (The results of the unit root tests on the first differences are not presented in order to save space).

\section{The long-run model of money demand}

Hence, on the basis of the unit root tests, we can conclude that M1, GDP and DENDEP are I(1) processes. All the variables in the empirical model are integrated of the same order, so we can proceed with the econometric analysis by testing for the presence of cointegration between these three variables. It was already mentioned that the concept of cointegration was introduced by Engle and Granger (1987) who showed that, even if the variables are non-stationary, some linear combination of them may be stationary, in which case they are said to be cointegrated. The economic interpretation of cointegration is that a long-run equilibrium relationship exists between a given set of variables.

We study the long-run relationship between money, income and interest rates by means of the maximum-likelihood approach to cointegration, introduced by Johansen (1988) and Johansen and Juselius (1990). This appears to be a commonly-used method to analyse cointegrated systems. In contrast to the procedure of Engle and Granger (1987), which is based on the residuals obtained from a single equation, Johansen's approach utilises the Vector Autoregression (VAR) framework. Here, the procedure begins with an unrestricted VAR and then the cointegration rank of the system is determined, showing the number of cointegrating vectors.

We begin our empirical modelling of the demand for money by specifying a VAR model containing the levels of the three variables from equation (4). Note that, a priori, all the variables in the money demand function are endogenous, which implies that we employ a non-structural VAR. When working with VARs, one needs to determine the lag length, which is usually done by means of one or more information criteria. We employed several information criteria and, as expected, the results differed sharply, with Akaike and Hannan-Quinn Information Criteria suggesting much greater lags, while the Schwarz Information Criterion selected a first-order VAR. Given the limited size of the sample, we decided to make a compromise between the results obtained from the three information criteria. Hence, we included four lags in the VAR, which seems reasonable given that we are working with quarterly data.

In order to determine the number of cointegrating vectors, we employed Johansen's two alternative test statistics: the trace of the stochastic matrix; and the maximum eigenvalue. The results of the two variants of Johansen's cointegration test are presented below: 
Table 3 - Cointegration test based on the trace of the stochastic matrix

\begin{tabular}{|l|c|c|c|}
\hline Null & Alternative & Statistic & $\mathbf{5 \%}$ critical value \\
\hline $\mathrm{r}=0$ & $\mathrm{r}>=1$ & 30.38127 & 24.27596 \\
\hline $\mathrm{r}<=1$ & $\mathrm{r}=2$ & 11.69149 & 12.32090 \\
\hline $\mathrm{r}<=2$ & $\mathrm{r}=3$ & 1.286008 & 4.129906 \\
\hline
\end{tabular}

Table 4 - Cointegration test based on the maximum eigenvalue

\begin{tabular}{|l|c|c|c|}
\hline Null & Alternative & Statistic & $\mathbf{5 \%}$ critical value \\
\hline $\mathrm{r}=0$ & $\mathrm{r}>=1$ & 18.68978 & 17.79730 \\
\hline $\mathrm{r}<=1$ & $\mathrm{r}=2$ & 10.40548 & 11.22480 \\
\hline $\mathrm{r}<=2$ & $\mathrm{r}=3$ & 1.286008 & 4.129906 \\
\hline
\end{tabular}

It can be seen that, in both cases, the test statistic exceeds the critical values at the $95 \%$ confidence level, suggesting that we can reject the null hypothesis of no cointegrating vectors in favour of the alternative. On the other hand, the obtained test statistic is not sufficient to reject the null of there being, at most, one cointegrating vector in favour of the alternative of two cointegrating vectors. Hence, based on the trace statistic and the maximum eigenvalue statistic, we can conclude that there is a cointegration relationship between the variables of interest and that this cointegrating vector can be regarded as the money demand function.

However, a note of caution is needed when interpreting these results: it is known that the results of Johansen's cointegration tests depend on the lag-length of the VAR. We mentioned above that, when determining the order of the VAR, two of the information criteria suggested that many lags should be included while one criterion pointed to only one lag. We are working with a small sample and do not want to lose too many degrees of freedom, so we have adopted a somewhat arbitrary approach to working with a VAR of fourth order. This decision had a substantial impact on the results of the cointegration test, which proved to be sensitive to the number of lags included in the VAR. Further, it should be mentioned that the cointegrating rank depends on the variant of the cointegration test, i.e. on whether the VAR includes intercept and/or trend. Finally, it was noted by Ericsson (1998: 299) that this sensitivity of the cointegration tests may reflect the choice of particular measure of variables in the empirical model.

When normalised with respect to $\mathrm{M} 1$, we obtain the following cointegration vector (with standard errors given in parentheses):

$$
\begin{array}{cc}
\mathrm{M} 1 & -0.607037 \mathrm{GDP}+5.406044 \mathrm{DENDEP} \sim \mathrm{I}(0) . \\
(0.02471) & (2.93254)
\end{array}
$$

The coefficients before the variables are of the expected sign, although it should be noted that the coefficient before DENDEP is significant only at the $10 \%$ level, while that before GDP is highly significant. Hence, the cointegrating vector can be interpreted 
as a money demand function, where money holdings are positively related to real income and negatively associated with the short-run interest rate.

Turning to the economic importance of the obtained coefficients, it can be seen that income elasticity is much lower than unity, i.e. it is closer to 0.5 . This result may reflect our modelling of the demand for narrow money, which serves for transaction purposes and not as an asset, so that economic agents tend to economise on their money holdings. In these regards, it is worth noting that recent institutional and technological innovations in the Macedonian payment system have increased the ability of economic agents to economise with money balances, thus reducing the income elasticity of the demand for narrow money. In terms of money demand theories, it seems that our empirical model supports the Baumol-Tobin framework. This tendency of economic agents to economise on money holdings is further confirmed by the pretty high coefficient before the interest rate, which is in line with the interest semi-elasticity usually found in countries with less-developed financial systems.

Figure 1 plots the cointegrating vector estimated with Johansen's approach. In these regards, the cointegrating vector might be taken as a measure of the deviation of money demand from its equilibrium level. It is shown that, over the whole period, the cointegrating vector lies below the zero line, which means that the demand for narrow money has been less than its equilibrium long-run level. This result reflects both the low income elasticity and the high interest rate elasticity of the demand for money, i.e. the tendency of economic agents to keep their holdings of money as low as possible.

At the same time, it seems that monetary policy has also been an important factor that has kept the demand for money below its equilibrium level. On the one hand, in order to defend the exchange rate peg, the central bank has maintained relatively high interest rates throughout the sample period, thus reducing the demand for money. On the other hand, during the second half of the 1990s the central bank employed direct instruments for controlling the money supply (credit ceilings), resulting in very low rates of monetary growth. The consequence of this tight monetary policy is that it has been difficult for economic agents to adjust their money holdings to the desired level. However, the overall macroeconomic environment has recently changed substantially (with quite high money growth rates and much lower interest rates), thus enabling economic agents to drive their money holdings to the long-run equilibrium level. 
Figure 1 - The cointegrating vector for the money demand

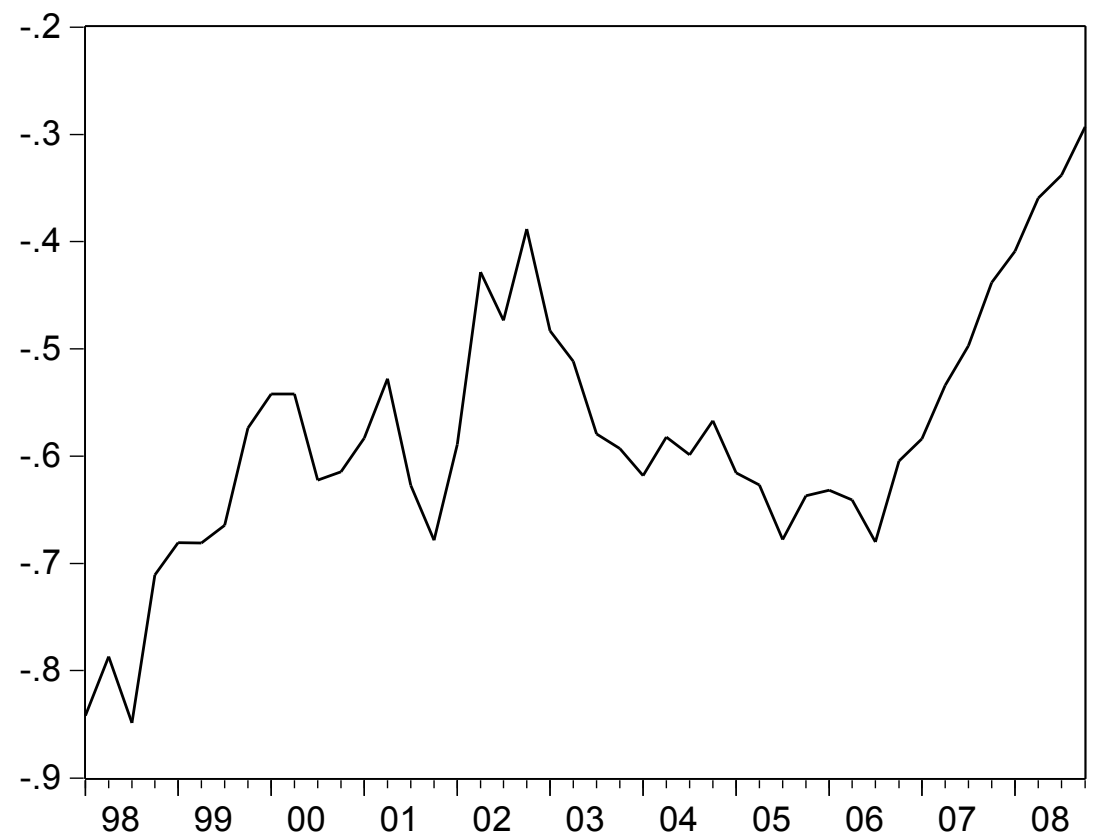

The short-run model of money demand

We analyse the short-run dynamics of money demand by means of the VEC model, which contains the first differences of all endogenous variables entering the system (real money, real income and the short-run interest rate) along with the error correction vector, which represents the deviations of the endogenous variables from their longrun equilibrium levels. The short-run model shows how the demand for money reverts to its long-run equilibrium level after having been disturbed by exogenous shocks.

Therefore, on the basis of the cointegration equation, the following Error Correction Model of the demand for narrow money was estimated:

$$
\begin{aligned}
& \Delta \mathrm{M}_{\mathrm{t}}=\beta_{0}+\beta_{1} \sum \Delta \mathrm{M}_{\mathrm{t}-\mathrm{i}}+\beta_{2} \sum \Delta \mathrm{GDP}_{\mathrm{t}-\mathrm{i}}+\beta_{1} \sum \Delta \operatorname{DENDEP}_{\mathrm{t}-\mathrm{i}}+\lambda \mathrm{ECM}_{\mathrm{t}-1}+\mathrm{u}_{\mathrm{t}} \\
& \text { where: } \quad \mathrm{ECM}_{\mathrm{t}-1}=\mathrm{M}_{\mathrm{t}-1}-0.607037 \mathrm{GDP}_{\mathrm{t}-1}+5.406044 \operatorname{DENDEP}_{\mathrm{t}-1}
\end{aligned}
$$

The estimates obtained from the short-run empirical model of the demand for money are given below: ${ }^{1}$

1 This study focuses on the demand for money, so we have not presented the estimates from the short-run model for GDP and DENDEP. 
Table 5 - Error Correction Model of the demand for money

\begin{tabular}{|c|c|c|c|}
\hline \multicolumn{4}{|c|}{$\begin{array}{l}\text { Dependent variable: } \Delta \mathrm{M} 1 \\
\text { Sample: } 1998 \mathrm{Q} 1-2008 \mathrm{Q} 4 \\
\text { Number of observations: } 44\end{array}$} \\
\hline Regressor & Coefficient & Standard error & t-statistics \\
\hline$\Delta \mathrm{M} 1(-1)$ & 0.211292 & 0.16782 & 1.25905 \\
\hline$\Delta \mathrm{M} 1(-2)$ & -0.268380 & 0.16440 & -1.63246 \\
\hline$\Delta \mathrm{M} 1(-3)$ & -0.004873 & 0.15940 & -0.03057 \\
\hline$\Delta \mathrm{GDP}(-1)$ & -0.212917 & 0.20181 & -1.05505 \\
\hline$\Delta \mathrm{GDP}(-2)$ & -0.447801 & 0.23282 & -1.92338 \\
\hline$\Delta \mathrm{GDP}(-3)$ & -0.170700 & 0.18104 & -0.94290 \\
\hline$\triangle \mathrm{DENDEP}(-1)$ & 3.065300 & 1.84455 & 1.66182 \\
\hline$\triangle \mathrm{DENDEP}(-2)$ & 1.266141 & 1.89475 & 0.66824 \\
\hline$\triangle \mathrm{DENDEP}(-3)$ & 0.049120 & 1.77842 & 0.02762 \\
\hline $\mathrm{ECM}(-1)$ & -0.070275 & 0.02009 & -3.49872 \\
\hline \multicolumn{4}{|c|}{$\begin{array}{l}\bar{R}^{2}=0.1503 \\
\text { Standard error of the regression: } 0.0467 \\
\text { LM-test for serial correlation: } 19.0588(0.0247)^{*} \\
\text { Jargue-Bera test for normality: } 16.0864(0.0133) \\
\text { Heteroskedasticity test: } 118.6562(0.5175)\end{array}$} \\
\hline
\end{tabular}

Note: The p-values for the diagnostic tests are given in parentheses.

The error correction term in the demand for money equation represents the mechanism by which the demand for money adjusts towards its long-run equilibrium level. Consequently, the coefficient before the error term should have a negative sign, revealing how much of the deviation from the equilibrium is adjusted within a single period. We can see that the error term bears the 'correct' sign and is highly significant, which confirms the existence of the cointegrating relationship. In fact, the above table shows that only the error term is significant at the $5 \%$ level, with almost all the other coefficients being insignificant even at the $10 \%$ level. Moreover, it is also obvious that the other coefficients in the short-run model bear the 'wrong' signs. Concerning the magnitude of the coefficient before the error term, this is quite low, suggesting a very slow adjustment of the demand for money towards its long-run equilibrium level. Indeed, the error correction term implies that less than $10 \%$ of the deviation from the equilibrium position is corrected in a single quarter, i.e. it takes three and a half years to restore long-run equilibrium. This result is in line with our explanation of Figure 1.

Ultimately, the diagnostic tests presented in Table 5 show that our short-run model is less than satisfactory because it suffers from serial correlation and, also, the residuals 
are not normally distributed (although in the equation for the demand for money, we cannot reject the null of normality). These weaknesses in the model should be taken seriously, but they do not necessarily disqualify it in terms of the possibility of drawing sound economic inferences. On the other hand, it is true that such shortcomings imply opportunities for the further development of the empirical model (Ericsson, 1998: 310).

\section{Stability of the demand for money}

Following the estimation of both the long-run and the short-run model, we address in this section the issue of the stability of the money demand function. Specifically, we want to check whether the estimated coefficients are stable over time. In these regards, it is worth noting that parameter constancy is of critical importance in the empirical modelling of money demand: it bears strong implications for the economic interpretation of the parameters as well as for policy evaluation across different regimes. Concerning the former, it is well-known that, in order to be relevant for the practical implementation of monetary policy, money demand needs to be stable. As for the latter, a constancy of the parameters in the money demand function is a necessary condition in the evaluation of the effects of monetary policy actions across different policy regimes in the light of the famous Lucas critique (Lucas, 1976). For a precise and very useful discussion on the importance of parameter constancy in the analysis of the demand for money, see Ericsson (1998: 299-303).

Figures 2 and 3 show the coefficients before real income and nominal interest rates estimated recursively, together with a confidence interval of $\phi 2$ standard errors. It is striking that the values of the coefficients remain quite stable over time, especially the coefficient before real income, which lies between 0.5 and 0.6 . The stability of the coefficient before nominal interest rates is not so pronounced, since it shows much wider variations although usually varying between -7 and -10 . In both cases, two outliers are present: one in the first quarter of 2005 and another one at the beginning of 2008. There is no obvious explanation for these large deviations, so we treat them as random outcomes. Therefore, we take this exercise as evidence in favour of the stability of the demand for money.

This finding is in contrast with the hypothesis of the alleged instability of money demand in Macedonia, which has always been taken as an a priori given but which has never been proven (or even investigated) empirically. In addition, the overall results of our study suggest that monetary aggregates might have an important role in the implementation of monetary policy within a different monetary policy framework (e.g. inflation targeting or the ECB framework). 
Figure 2 - Recursive coefficients of income elasticity

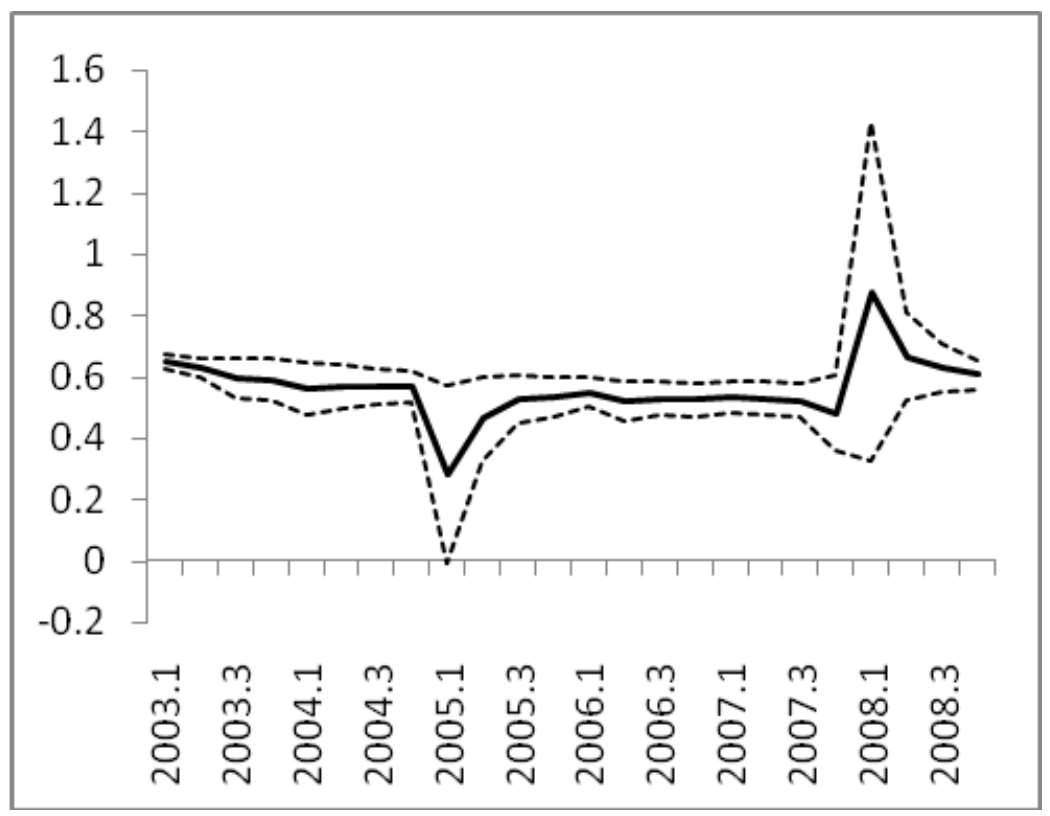

Figure 3 - Recursive coefficients of interest rate semi-elasticity

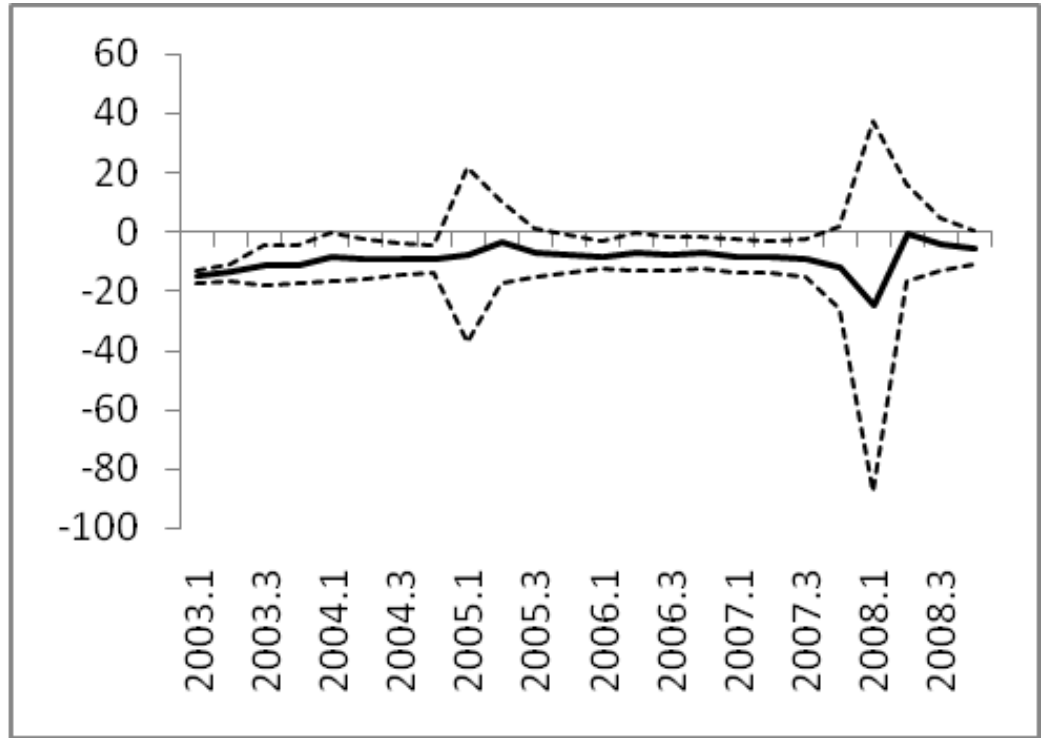




\section{Conclusion}

In this article, we have provided an empirical analysis of the demand for narrow money in Macedonia during the post-stabilisation period. Specifically, we first estimated the long-run model and found a cointegrating relationship between real money, real income and nominal interest rates, which can be interpreted as the money demand function. Regarding the magnitudes of the coefficients in the long-run model, we found income elasticity below unity and high interest rate semi-elasticity. We then turned to investigate the short-run dynamics of the demand for money, employing the standard Error Correction Model. The error correction term appeared to be statistically significant, thus confirming the existence of cointegration although the estimated coefficient was very low, suggesting slow adjustment towards long-run equilibrium. Finally, we checked for parameter constancy and found that an empirically stable money demand function could be established.

Taken together, the results of our study imply that, in case the existing monetary policy strategy (i.e. of exchange rate targeting) is substituted for an alternative framework (such as inflation targeting or an ECB-style approach), narrow money might have some role in the practical implementation of monetary policy.

However, in order to be able to derive firm recommendations for policy-makers, several open issues should be further investigated. First, this study deals only with the demand for narrow money and, hence, it would be interesting to analyse the demand for broader monetary aggregates, too. Second, Macedonia is a small, open economy with a high degree of currency substitution, so the inclusion of foreign returns in the money demand function (in terms of foreign interest rates and foreign exchange rates) might produce valuable insights. Third, Macedonia has seen low inflation rates during the last fifteen years, but its previous long experience with high inflation might justify the possible inclusion of inflation in the empirical model. Finally, in future research, it would be useful to examine the robustness of the results across various econometric techniques and assumptions (VARs of different lag-length, alternative approaches to cointegration, etc.).

\section{References}

Andersen, Allan Bødskov (2004) Money Demand in Denmark 1980-2002 Danmarks Nationalbank Working Paper No. 18, June.

Bahmani-Oskooee, Mohsen and Raymond Chi Wing Ng (2002) 'Long-Run Demand for Money in Hong Kong: An Application of the ARDL Model' International Journal of Business and Economics 1(2): 147-155.

Calza, Alessandro, Dieter Gerdesmeier and Joaquim Levy (2001) Euro Area Money Demand: Measuring the Opportunity Cost Appropriately IMF Working Paper $01 / 179$, November.

Dreger, Christian, Hans-Eggert Reimers and Barbara Roffia (2006) Long-Run Money Demand in the New EU Member States With Exchange Rate Effects European Central Bank Working Paper Series No. 628, May. 
Engle, R. F and C. W. J. Granger (1987) 'Co-Integration and Error-Correction: Representation, Estimation, and Testing' Econometrica 55: 251-76.

Ericsson, Neil R (1998) 'Empirical Modelling of Money Demand' Empirical Economics 23: 295-315.

Ericsson, Neil R, David F. Hendry and Kevin M. Prestwich (1998) 'The Demand for Broad Money in United Kingdom, 1878-1993' Scandinavian Journal of Economics 100(1): 289-324.

Golinelli, Roberto and Sergio Pastorello (2002) 'Modeling the demand for M3 in the Euro Area' The European Journal of Finance 8(4): 371-401, December.

Halicioglu, Ferda and Mehmet Ugur (2005) 'On Stability of the Demand for Money in a Developing OECD Country: The Case of Turkey' Global Business and Economic Review 7(2/3): 203-213.

Johansen, Soren (1998) 'Statistical Analysis of Cointegration Vectors' Journal of Economic Dynamics and Control 12: 231-254.

Johansen, S and Kristina Juselius (1990) 'Maximum Likelihood Estimation and Inference on Cointegration, with Application for the Demand for Money' Oxford Bulletin of Economics and Statistics 52: 169-210.

Jonsson, Gunnar (2001) 'Inflation, Money Demand and Purchasing Power Parity in South Africa' IMF Staff Papers 48(2): 243-265.

Kalra, Sanjay (1999) 'Inflation and Money Demand in Albania' Russian and East European Finance and Trade 35(6): 82-105.

Knell, Markus and Helmut Stix (2004) Three Decades of Money Demand Studies. Some Differences and Remarkable Similarities Oesterreichische Nationalbank Working Paper 88, May.

Lucas, Robert E, Jr. (1976) 'Econometric Policy Evaluation: A Critique' in K. Brunner and A. Meltzer (Eds.) The Phillips Curve and Labor Markets Vol. 1. CarnegieRochester Conference Series of Public Policy.

Mutluer, Defne and Yasemin Barlas (2002) 'Modeling Turkish Broad Money Demand' Central Bank Review 2: 55-75.

Nachega, Jean-Claude (2001) A Cointegration Analysis of Broad Money Demand in Cameroon IMF Working Paper WP/01/26, March.

Piñón-Farah, Marco (1998) Demand for Money in Mozambique: Was There a Structural Break? IMF Working Paper 98/157, November.

Siliverstovs, Boriss (2007) Money Demand in Estonia DIW Berlin Discussion Papers 675, March.

Sriram, Subramanian S (1999) Demand for M2 in an Emerging-Market Economy: An Error-Correction Model for Malaysia IMF Working Paper 99/173, December.

Sriram, Subramanian S (2001) 'A Survey of Recent Empirical Money Demand Studies' IMF Staff Papers 47(3): 334-365. 